\title{
Application of cardiac surgery techniques to improve the results of cardiopulmonary resuscitation after cardiac arrest: Controlled automated reperfusion of the whole body
}

Friedhelm Beyersdorf, MD, Georg Trummer, MD, Christoph Benk, PhD, and Jan-Steffen Pooth, MD

Video clip is available online.

Until now, the overall results (survival and neurologic outcome) of cardiopulmonary resuscitation (CPR) after cardiac arrest (CA) have been quite dismal. They have improved when compared with the outcome over the past number of decades but are still far from ideal. This is true for both out-of-hospital cardiac arrest ${ }^{1,2}$ and in-hospital cardiac arrest. ${ }^{3}$ Survival after out-of-hospital cardiac arrest is reported to be in the range of $8 \%$ to $10 \%{ }^{2}$ with neurologic damage found in many of the survivors. ${ }^{4}$ Nevertheless, all major efforts in the field of resuscitation (including CPR by laymen and professionals, improved alarm systems, and better medications) are more than valued and have resulted in some very favorable outcomes.

The pathophysiologic mechanism of injury after CA is ischemia reperfusion, not only in vital organs but also to the whole body (Figure 1). After ischemia induced by $\mathrm{CA}$, low-flow reperfusion is usually established during the first phase by CPR (basic life support and advanced life support). CPR may result in the return of spontaneous circulation or (in selected cases) in the use of extracorporeal circulation. Even if return of spontaneous circulation could be established, intermittent phases of additional CA may occur.

Therefore, the reasons for the poor results of CPR after CA can be classified as:

\footnotetext{
From the Department of Cardiovascular Surgery, University Hospital Freiburg, and Medical Faculty of the Albert-Ludwigs-University Freiburg, Freiburg, Germany. Received for publication July 31, 2021; accepted for publication Oct 13, 2021; available ahead of print Nov 3, 2021.

Address for reprints: Friedhelm Beyersdorf, MD, Department of Cardiovascular Surgery, University Hospital Freiburg, Hugstetterstr 55, D-79106 Freiburg, Germany (E-mail: friedhelm.beyersdorf@uniklinik-freiburg.de).

JTCVS Open 2021;8:47-52

2666-2736

Copyright (C) 2021 The Author(s). Published by Elsevier Inc. on behalf of The American Association for Thoracic Surgery. This is an open access article under the CC BY-NC-ND license (http://creativecommons.org/licenses/by-nc-nd/4.0/).

https://doi.org/10.1016/j.xjon.2021.10.006
}
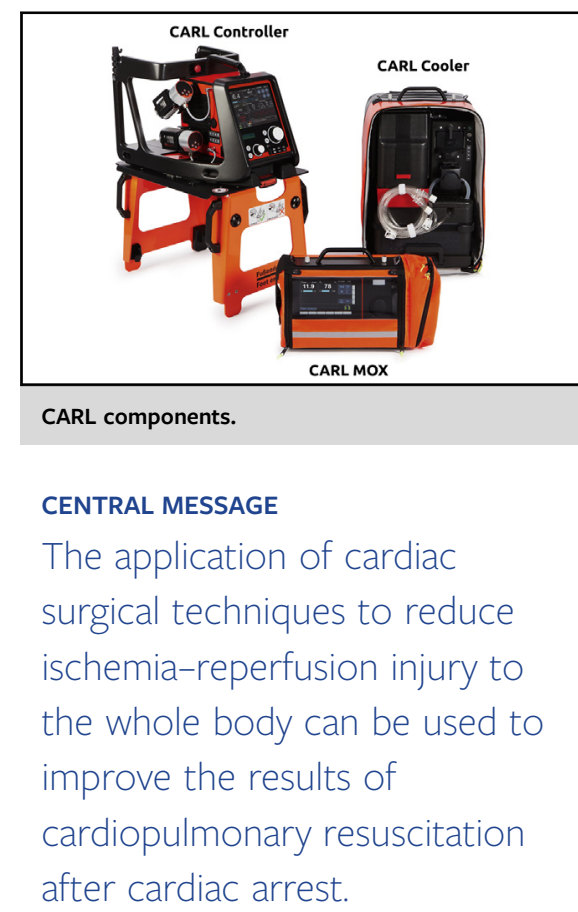

See Commentary on page 53 .

- Critical underlying disease (eg, left ventricle rupture, free ruptured thoracic aortic aneurysms, and massive cerebral bleeding),

- Multimorbidities (eg, end-stage lung disease, chronic renal/liver failure, frailty, insulin-dependent diabetes, severe neurologic disorders, and end-stage cancer), and

- Acute multiorgan damage after ischemia-reperfusion injury.

To minimize this whole-body ischemia-reperfusion injury, we introduced the concept of controlled automated reperfusion of the whole body (CARL), which is based on cardiac surgical techniques, developed over the past 20 to 30 years (Figure 1,C). CARL was developed to reduce/avoid ischemia-reperfusion injury after CA but it has not been found to be successful in critical diseases or in multimorbid patients.

Intensive work in this field has resulted in previously unknown success in myocardial protection as well as organ protection in general. ${ }^{5-7}$ Indeed, over the past decade a new 

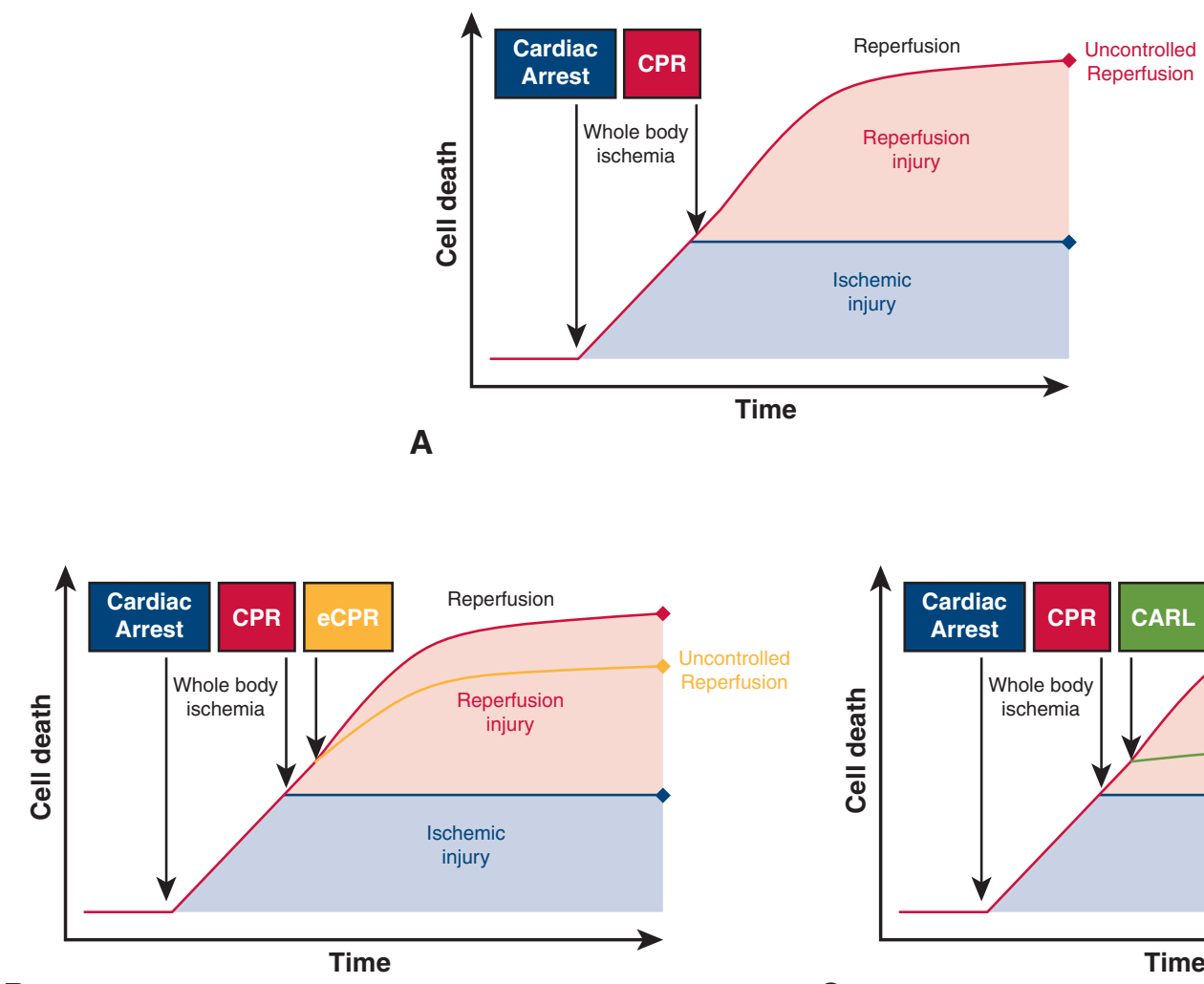

B

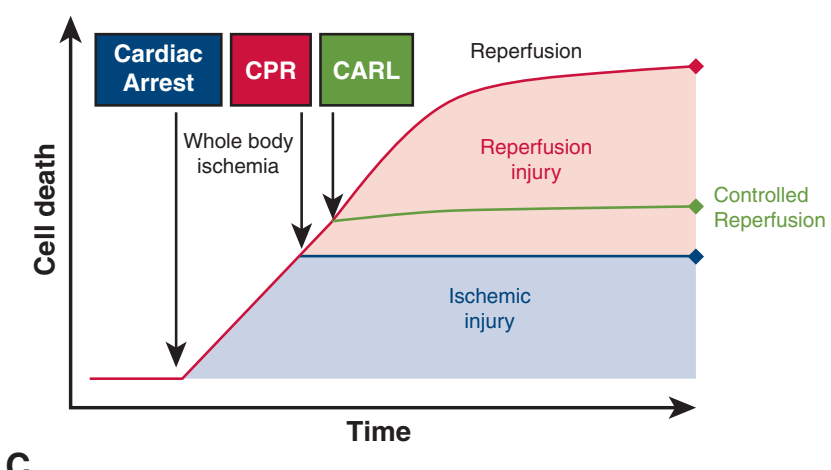

FIGURE 1. Development of ischemia reperfusion injury in treatments of cardiac arrest. Cardiac arrest results in whole body ischemia. A, Cardiopulmonary resuscitation $(C P R)$ may restore minimal blood flow by chest compressions and few or no ventilation (minimal uncontrolled reperfusion; ie, unmodified blood, low flow, low pressure, minimal, or no oxygen). B, Extracorporeal CPR $(e C P R)$ has shown beneficial effects but represents an undefined therapy approach. C, Controlled automated reperfusion of the whole body $(C A R L)$ reduces reperfusion injury by control and modification of more than 10 blood parameters and control and modification of specific reperfusion parameters (for details see Table 1).

field of research in applying innovative cardiac surgical techniques to the field of $\mathrm{CA}$ and $\mathrm{CPR}^{8-14}$ has emerged.

The aim of this Invited Expert Opinion article is to review the pathophysiology of ischemia-reperfusion injury after $\mathrm{CA}$, the scientific background and clinical development for CARL, and the latest experimental data. The CARL concept is also addressed in Video 1.

\section{SCIENTIFIC BACKGROUND}

Our group in Freiburg, in cooperation with our colleagues from Yale University and the Max-Planck-Institute in Cologne, Germany, has recently published a review in Nature Reviews Neuroscience describing the scientific background of the ischemia tolerance of the brain as the most ischemia-sensible organ and opportunities to treat ischemia reperfusion injury (IRI) by modifications and control of the initial reperfusion phase. ${ }^{14}$ Previous reports have already shown that the ischemic tolerance, even of the brain, is substantially prolonged if appropriate reperfusion conditions are applied. ${ }^{11,15,16}$

After more than 15 to 20 years of research, our group has developed a technique called CARL (Figure 2), which enables users to clinically apply many of the important basic science principles recently outlined in detail. ${ }^{14}$ The reperfusion parameters, which are controlled by our CARL technique, are summarized in Table 1.

In addition to the development of the scientific background for this new approach, ${ }^{9-14}$ innovative

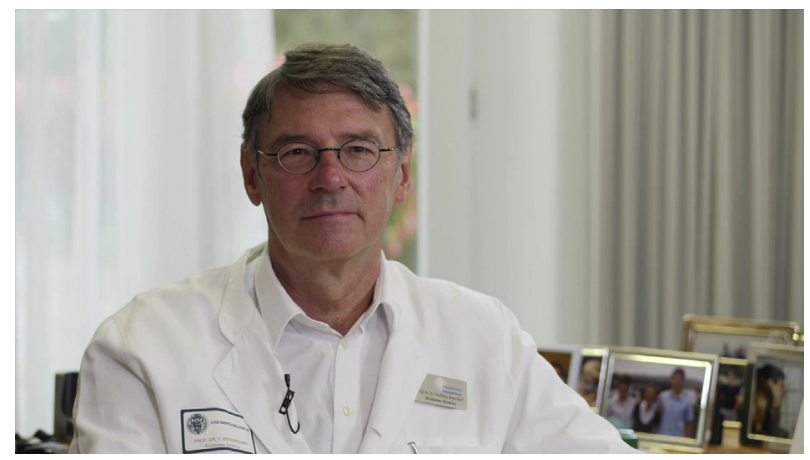

VIDEO 1. Professor Beyersdorf explains the rationale of controlled automated reperfusion of the whole body (CARL). Video available at: https://www.jtcvs.org/article/S2666-2736(21)00356-9/fulltext. 


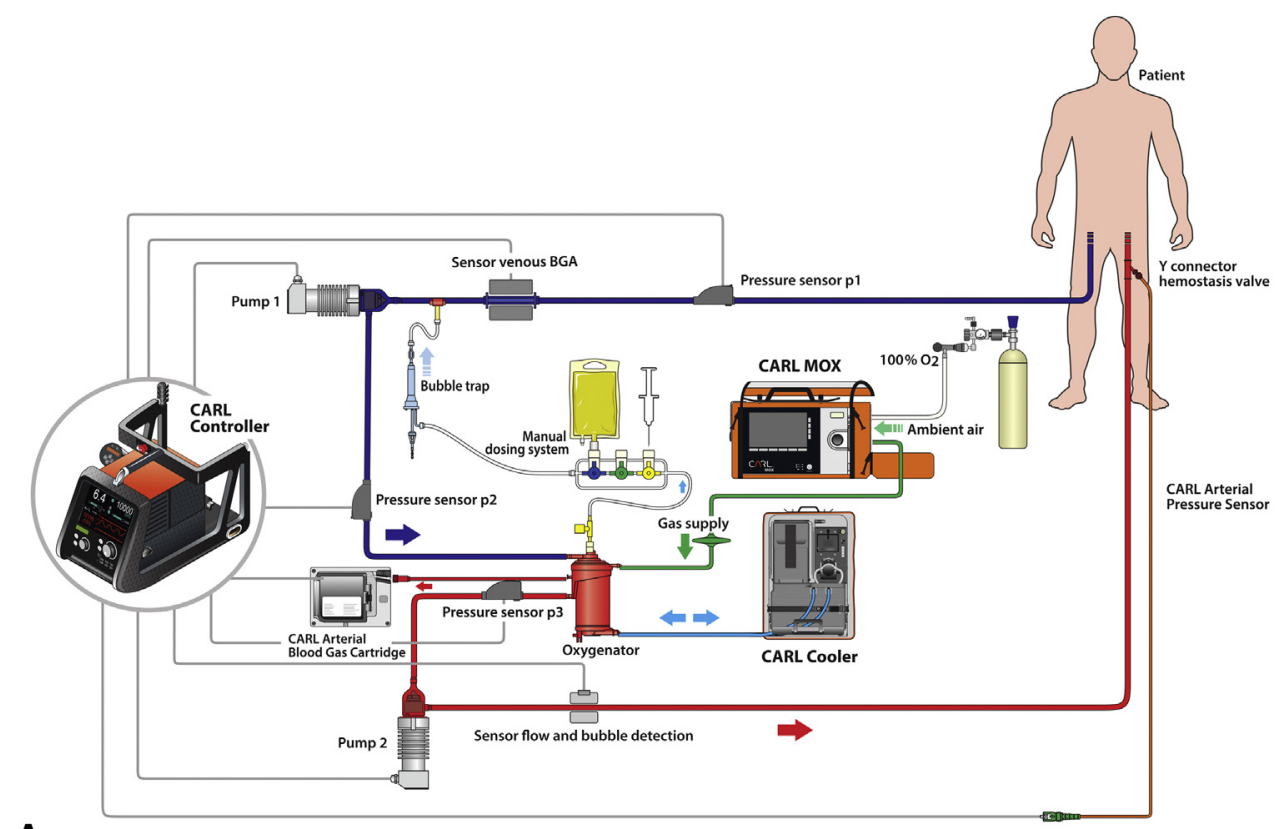

A

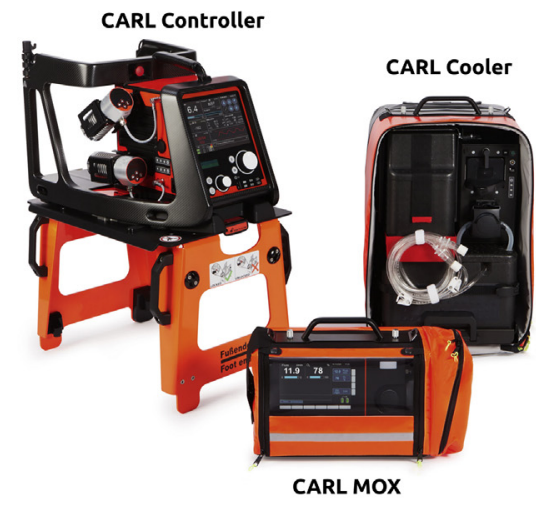

FIGURE 2. A, Schematic drawing of the controlled automated reperfusion of the whole body (CARL) set up. B, Picture of CARL controller, CARL oxygenation controller (CARL MOX, Resuscitec GmbH, Freiburg, Germany), and CARL cooler. BGA, Blood gas analysis.

technical developments have evolved and have resulted in a new, portable device (the CARL Controller, Resuscitec $\mathrm{GmbH}$, Freiburg im Breisgau, Germany), which allows the principles of the CARL therapy to be applied (Table 1) in and out of the hospital, including controlled oxygenation (the CARL MOX) and immediate cooling of the patient (the CARL Cooler) (Figure 2). This technology can be used routinely inside the hospital, but is also intended to be used outside the hospital in selected cases. The out-of-hospital use is already being practiced in some centers in Germany.

To improve the results of CPR after CA, the use of extracorporeal circulation systems was introduced by several groups around the world. ${ }^{50-53}$ Although its superiority over standard CPR techniques has not been established, there are several indications showing the beneficial effects in selected patients. Nevertheless, extracorporeal CPR does not address the consequences of ischemia-reperfusion injury directly (Figure 1). Therefore, based on the current pathophysiologic knowledge for brain viability after ischemia ${ }^{14}$ the CARL therapy has been developed to control a number of different aspects of IRI, which are outlined in Tables 1 and 2.

\section{PRELIMINARY CLINICAL DATA}

The resulting clinical data of preliminary pilot studies using this new technique are very promising. ${ }^{54-56}$ In the preliminary clinical study, 7 out of 14 surviving patients regained full consciousness, whereas 6 of these 7 were assigned to cerebral performance class $1 .^{55}$

However, before any meaningful conclusions can be drawn, the ongoing multicenter, European clinical study (postmarket clinical follow-up) (DRKS00018967), 
TABLE 1. Rationale for controlled automated reperfusion of the whole body (CARL)

\begin{tabular}{|c|c|c|c|}
\hline Overall & Parameter & Rationale & Publications \\
\hline \multirow[t]{15}{*}{$\begin{array}{l}\text { Composition of } \\
\text { reperfusate }\end{array}$} & Calcium & $\begin{array}{l}\text { Lowering serum calcium to prevent cellular calcium uptake in first minutes of reperfusion to } \\
\text { avoid additional cell damage }\end{array}$ & $\operatorname{Refs}^{17-23}$ \\
\hline & Sodium & $\begin{array}{l}\text { Avoid excessive alterations of serum sodium levels with respect to cerebral volume } \\
\text { displacements and subsequent cerebral edema }\end{array}$ & $\operatorname{Refs}^{17,24,25}$ \\
\hline & \multirow[t]{2}{*}{ Potassium } & $\begin{array}{l}\text { Secondary cardioplegia; that is, convert ventricular flutter/fibrillation into asystole with } \\
\text { subsequent minimized oxygen demand of the myocardium. }\end{array}$ & \multirow[t]{2}{*}{$\operatorname{Refs}^{26}$} \\
\hline & & $\begin{array}{l}\text { Secondary cardioplegia using elevated potassium levels is only applicable when stable } \\
\text { circulatory support is provided by extracorporeal circulation }\end{array}$ & \\
\hline & Magnesium & Increase magnesium to support membrane stabilization & $\operatorname{Ref}^{27}$ \\
\hline & Viscosity & Lowering viscosity to improve perfusion by reducing the no-reflow-phenomenon & $\operatorname{Refs}^{28}$ \\
\hline & Hemodilution & Improving perfusion by reducing the no-reflow-phenomenon & $\operatorname{Refs}^{28,29}$ \\
\hline & Osmolality & Increase serum osmolality to limit cerebral edema and decrease vasopressor requirements & $\operatorname{Refs}^{30,31}$ \\
\hline & $\begin{array}{l}\text { Colloid osmotic } \\
\text { pressure }\end{array}$ & $\begin{array}{l}\text { Increase colloid osmotic pressure to limit cerebral edema and decrease vasopressor } \\
\text { requirements }\end{array}$ & $\operatorname{Refs}^{30,31}$ \\
\hline & Oxygen & Lowering oxygen to limit generation of oxygen free radicals & $\operatorname{Refs}^{23,32}$ \\
\hline & Carbon dioxide & Permission of temporary elevated carbon dioxide levels to support $\mathrm{pH}$-stat strategy & $\operatorname{Ref}^{33}$ \\
\hline & $\mathrm{pH}$ & $\begin{array}{l}\text { pH-stat strategy to lower cellular metabolism during first } 30 \mathrm{~min} \text { of reperfusion until substrates } \\
\text { are replenished }\end{array}$ & $\operatorname{Ref}^{33}$ \\
\hline & Lidocaine & Addition of lidocaine for rhythm conversion or stabilization & $\operatorname{Refs}^{27,34,35}$ \\
\hline & Anticoagulation & Avoid clotting and improve microcirculatory perfusion & $\operatorname{Ref}^{36}$ \\
\hline & $\begin{array}{l}\text { Free radical } \\
\text { scavengers }\end{array}$ & Addition of free radical scavengers to limit reactive oxygen species & $\operatorname{Refs}^{23,32,37-39}$ \\
\hline \multirow[t]{4}{*}{$\begin{array}{l}\text { Conditions of } \\
\text { reperfusion }\end{array}$} & Flow & $\begin{array}{l}\text { High Flow to enhance hemodynamic power to reopen capillary flow areas and counteract the } \\
\text { no-reflow-phenomenon especially in the brain }\end{array}$ & $\operatorname{Refs}^{40,41}$ \\
\hline & Temperature & Immediate mild hypothermia to lower cellular oxygen demand & $\operatorname{Refs}^{33,42-49}$ \\
\hline & Pressure & High pressure to reduce the no-reflow-phenomenon & $\operatorname{Refs}^{28,40,41}$ \\
\hline & Pulsatility & $\begin{array}{l}\text { Enhanced hemodynamic power to reopen capillary flow areas and counteract the no-reflow- } \\
\text { phenomenon, especially in the brain }\end{array}$ & $\operatorname{Ref}^{40}$ \\
\hline
\end{tabular}

Ref, Reference.

sponsored by a European Union grant (Horizon 2020) has to be finalized. The enrollment was unfortunately delayed by the COVID-19 pandemic and is now expected to be closed in the coming 12 to 18 months.

TABLE 2. Comparison of diagnostic and therapeutic options of cardiopulmonary resuscitation $(C P R)$, extracorporeal CPR $(e C P R)$, and controlled automated reperfusion of the whole body $(C A R L)$ after out-of-hospital cardiac arrest

\begin{tabular}{|c|c|c|c|}
\hline Option & CPR & eCPR & CARL \\
\hline Venoarterial perfusion and oxygenation & $(レ)$ & $\swarrow$ & $\swarrow$ \\
\hline High arterial perfusion pressure & - & - & 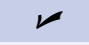 \\
\hline Pulsatile arterial blood flow & - & - & レ \\
\hline High arterial blood flow & - & - & 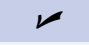 \\
\hline Immediate hypothermia & - & - & レ \\
\hline Continous BGA (venous and arterial) & - & - & レ \\
\hline Controlled oxygenation & - & - & レ \\
\hline Hypocalcemia & - & - & レ \\
\hline Hyperkalemia & - & - & レ \\
\hline Hyperosmolarity & - & - & レ \\
\hline
\end{tabular}

\section{CONCLUSIONS}

The application of cardiac surgical techniques and innovative approaches to reduce IRI after CA has shown superior outcomes in different experimental models. Extensive basic research has been performed to develop new treatment modalities and to improve results after CA. This knowledge has led to innovative technologies that enable the application of these novel therapeutic principles in clinical practice. Preliminary clinical data have shown very promising results.

\section{Conflict of Interest Statement}

Dr Beyersdorf is founder and shareholder of Resuscitec $\mathrm{GmbH}$, a start-up company of the University Hospital Freiburg. Drs Trummer and Benk are part-time employees and shareholders of Resuscitec GmbH. Dr Pooth is a part-time employee of Resuscitec GmbH.

The Journal policy requires editors and reviewers to disclose conflicts of interest and to decline handling or reviewing manuscripts for which they may have a conflict of interest. The editors and reviewers of this article have no conflicts of interest. 


\section{References}

1. Virani SS, Alonso A, Benjamin EJ, Bittencourt MS, Callaway CW, Carson AP, et al. Heart Disease and Stroke Statistics-2020 update: a report from the American Heart Association. Circulation. 2020;141:e139-596.

2. Bougouin W, Dumas F, Lamhaut L, Marijon E, Carli P, Combes A, et al. Extracorporeal cardiopulmonary resuscitation in out-of-hospital cardiac arrest: a registry study. Eur Heart J. 2020;41:1961-71.

3. Perkins GD, Gräsner J-T, Semeraro F, Olasveengen T, Soar J, Lott C, et al. European Resuscitation Council Guidelines 2021: executive summary. Resuscitation. 2021;161:1-60.

4. Moulaert VRMP, Verbunt JA, van Heugten CM, Wade DT. Cognitive impairments in survivors of out-of-hospital cardiac arrest: a systematic review. Resuscitation. 2009;80:297-305.

5. Beyersdorf F, Kirsh M, Buckberg GD, Allen BS. Warm glutamate/aspartateenriched blood cardioplegic solution for perioperative sudden death. J Thorac Cardiovasc Surg. 1992;104:1141-7.

6. Beyersdorf $F$. The use of controlled reperfusion strategies in cardiac surgery to minimize ischaemia/reperfusion damage. Cardiovasc Res. 2009;83:262-8.

7. Allen BS, Veluz JS, Buckberg GD, Aeberhard E, Ignarro LJ. Deep hypothermic circulatory arrest and global reperfusion injury: avoidance by making a pump prime reperfusate-a new concept. J Thorac Cardiovasc Surg. 2003; 125:625-32.

8. Trummer G, Foerster K, Buckberg GD, Benk C, Heilmann C, Mader I, et al. Successful resuscitation after prolonged periods of cardiac arrest: a new field in cardiac surgery. J Thorac Cardiovasc Surg. 2010;139:1325-32.

9. Foerster K, D’Inka M, Beyersdorf F, Benk C, Nguyen-Thanh T, Mader I, et al. Prolonged cardiac arrest and resuscitation by extracorporeal life support: favourable outcome without preceding anticoagulation in an experimental setting. Perfusion. 2013;28:520-8.

10. Trummer G, Foerster K, Buckberg G, Benk C, Mader I, Heilmann C, et al. Superior neurologic recovery after 15 minutes of normothermic cardiac arrest using an extracorporeal life support system for optimized blood pressure and flow. Perfusion. 2014;29:130-8.

11. Taunyane IC, Benk C, Beyersdorf F, Foerster K, Cristina Schmitz H, Wittmann K, et al. Preserved brain morphology after controlled automated reperfusion of the whole body following normothermic circulatory arrest time of up to 20 minutes. Eur J Cardiothorac Surg. 2016;50:1025-34.

12. Kreibich M, Trummer G, Beyersdorf F, Scherer C, Förster K, Taunyane I, et al. Improved outcome in an animal model of prolonged cardiac arrest through pulsatile high pressure controlled automated reperfusion of the whole body: animal model of prolonged CA through pulsatile high pressure CARL. Artif Organs. 2018;42:992-1000.

13. Foerster K, Benk C, Beyersdorf F, Cristina Schmitz H, Wittmann K, Taunyane I, et al. Twenty minutes of normothermic cardiac arrest in a pig model: the role of short-term hypothermia for neurological outcome. Perfusion. 2018;33:270-7.

14. Daniele SG, Trummer G, Hossmann KA, Vrselja Z, Benk C, Gobeske KT, et al. Brain vulnerability and viability after ischaemia. Nat Rev Neurosci. 2021;22: 553-72.

15. Hossmann K-A, Schmidt-Kastner R, Grosse Ophoff B. Recovery of integrative central nervous function after one hour global cerebro-circulatory arrest in normothermic cat. J Neurol Sci. 1987;77:305-20.

16. Vrselja Z, Daniele SG, Silbereis J, Talpo F, Morozov YM, Sousa AMM, et al. Restoration of brain circulation and cellular functions hours post-mortem. Nature. 2019;568:336-43.

17. Blaustein MP, Lederer WJ. Sodium/calcium exchange: its physiological implications. Physiol Rev. 1999;79:763-854.

18. Choi DW. Calcium-mediated neurotoxicity: relationship to specific channel types and role in ischemic damage. Trends Neurosci. 1988;11:465-9.

19. Taunyane IC, Benk C, Beyersdorf F, Foerster K, Schmitz HC, Wittmann K, et al. Preserved brain morphology after controlled automated reperfusion of the whole body following normothermic circulatory arrest time of up to 20 minutes. Eur J Cardiothorac Surg. 2016;50:1025-34.

20. Kristián T, Siesjö BK. Calcium in ischemic cell death. Stroke. 1998;29:705-18.

21. Orrenius S, Zhivotovsky B, Nicotera P. Regulation of cell death: the calcium-apoptosis link. Nat Rev Mol Cell Biol. 2003;4:552-65.

22. Xiong Z-G, Zhu X-M, Chu X, Minami M, Hey J, Wei W-L, et al. Neuroprotection in ischemia. Cell. 2004;118:687-98.

23. Starkov AA, Chinopoulos C, Fiskum G. Mitochondrial calcium and oxidative stress as mediators of ischemic brain injury. Cell Calcium. 2004;36: 257-64.
24. Jiang C, Agulian S, Haddad GG. Cl- and $\mathrm{Na}+$ homeostasis during anoxia in rat hypoglossal neurons: intracellular and extracellular in vitro studies. J Physiol. 1992;448:697-708.

25. Xie Y, Dengler K, Zacharias E, Wilffert B, Tegtmeier F. Effects of the sodium channel blocker tetrodotoxin (TTX) on cellular ion homeostasis in rat brain subjected to complete ischemia. Brain Res. 1994;652:216-24.

26. Liakopoulos OJ, Allen BS, Buckberg GD, Hristov N, Tan Z, Villablanca JP, et al. Resuscitation after prolonged cardiac arrest: role of cardiopulmonary bypass and systemic hyperkalemia. Ann Thorac Surg. 2010;89:1972-9.

27. Letson HL, Granfeldt A, Jensen TH, Mattson TH, Dobson GP. Adenosine, lidocaine, and magnesium support a high flow, hypotensive, vasodilatory state with improved oxygen delivery and cerebral protection in a pig model of noncompressible hemorrhage. J Surg Res. 2020;253:127-38.

28. Fischer EG, Ames A. Studies on mechanisms of impairment of cerebral circulation following ischemia: effect of hemodilution and perfusion pressure. Stroke. 1972;3:538-42.

29. Olsson Y, Hossmann K-A. The effect of intravascular saline perfusion on the sequelae of transient cerebral ischemia: light and electron microscopial observations. Acta Neuropathol (Berlin). 1971;17:68-79.

30. Jungner M, Grände P-O, Mattiasson G, Bentzer P. Effects on brain edema of crystalloid and albumin fluid resuscitation after brain trauma and hemorrhage in the rat. Anesthesiology. 2010;12:1194-203.

31. Golab HD, Scohy TV, de Jong PL, Kissler J, Takkenberg JJ, Bogers AJ. Relevance of colloid oncotic pressure regulation during neonatal and infant cardiopulmonary bypass: a prospective randomized study. Eur J Cardiothorac Surg. 2011; 39:886-91.

32. Chan PH. Reactive oxygen radicals in signaling and damage in the ischemic brain. J Cereb Blood Flow Metab. 2001;21:2-14.

33. Yenari M, Kitagawa K, Lyden P, Perez-Pinzon M. Metabolic downregulation: a key to successful neuroprotection? Stroke. 2008;39:2910-7.

34. Bergey JL, Nocella K, McCallum JD. Acute coronary artery occlusionreperfusion-induced arrhythmias in rats, dogs and pigs: antiarrhythmic evaluation of quinidine, procainamide and lidocaine. Eur J Pharmacol. 1982;81:205-16.

35. Sanfilippo F, Corredor C, Santonocito C, Panarello G, Arcadipane A, Ristagno G et al. Amiodarone or lidocaine for cardiac arrest: a systematic review and metaanalysis. Resuscitation. 2016;10:31-7.

36. Foerster K, DInka M, Beyersdorf F, Benk C, Nguyen-Thanh T, Mader I, et al Prolonged cardiac arrest and resuscitation by extracorporeal life support: favourable outcome without preceding anticoagulation in an experimental setting. Perfusion. 2013;28:520-8.

37. Kawase M, Murakami K, Fujimura M, Morita-Fujimura Y, Gasche Y, Kondo T, et al. Exacerbation of delayed cell injury after transient global ischemia in mutant mice with CuZn superoxide dismutase deficiency. Stroke. 1999;30:1962-8.

38. Chan PH. Mitochondria and neuronal death/survival signaling pathways in cerebral ischemia. Neurochem Res. 2004;29:1943-9.

39. Suzuki J, Fujimoto S, Mizoi K, Oba M. The protective effect of combined administration of anti-oxidants and perfluorochemicals on cerebral ischemia. Stroke. 1984;15:672-9.

40. Kreibich M, Trummer G, Beyersdorf F, Scherer C, Förster K, Taunyane I, et al Improved outcome in an animal model of prolonged cardiac arrest through pulsatile high pressure controlled automated reperfusion of the whole body: animal model of prolonged CA through pulsatile high pressure CARL. Artif Organs. 2018;42:992-1000.

41. Trummer G, Foerster K, Buckberg GD, Benk C, Mader I, Heilmann C, et al. Superior neurologic recovery after 15 minutes of normothermic cardiac arrest using an extracorporeal life support system for optimized blood pressure and flow. Perfusion. 2014;29:130-8.

42. Foerster K, Benk C, Beyersdorf F, Schmitz HC, Wittmann K, Taunyane I, et al Twenty minutes of normothermic cardiac arrest in a pig model: the role of shortterm hypothermia for neurological outcome. Perfusion. 2018;33:270-7.

43. Ehrlich MP, McCullough JN, Zhang N, Weisz DJ, Juvonen T, Bodian CA, et al. Effect of hypothermia on cerebral blood flow and metabolism in the pig. Ann Thorac Surg. 2002;73:191-7.

44. Dankiewicz J, Cronberg T, Lilja G, Jakobsen JC, Levin H, Ullén S, et al. Hypothermia versus normothermia after out-of-hospital cardiac arrest. $N$ Engl J Med. 2021:384:2283-94.

45. Aki M, Sieweke J-T, Zauner F, Garcheva V, Tongers J, Napp C, et al. Mortality in patients with out-of-hospital cardiac arrest undergoing a standardized protoco including therapeutic hypothermia and routine coronary angiography. JACC Cardiovasc Interv. 2018;11:1811-20. 
46. Tisherman SA, et al. Therapeutic deep hypothermic circulatory arrest in dogs: a resuscitation modality for hemorrhagic shock with 'irreparable' injury. J Trauma. 1990;30:836-47.

47. Tisherman SA, Safar P, Radovsky A, Peitzman A, Marrone G, Kuboyama K, et al. Profound hypothermia (less than $10^{\circ} \mathrm{C}$ ) compared with deep hypothermia $\left(15^{\circ} \mathrm{C}\right)$ improves neurologic outcome in dogs after two hours' circulatory arrest induced to enable resuscitative surgery. J Trauma. 1991;31:1051-61.

48. Alam HB, Chen Z, Honma K, Koustova E, Querol RILC, Jaskille A, et al. The rate of induction of hypothermic arrest determines the outcome in a swine model of lethal hemorrhage. J Trauma Inj Infect Crit Care. 2004;57:961-9.

49. Erecinska M, Thoresen M, Silver IA. Effects of hypothermia on energy metabolism in mammalian central nervous system. J Cereb Blood Flow Metab. 2003;23:513-30.

50. Pappalardo F, Montisci A. What is extracorporeal cardiopulmonary resuscitation? J Thorac Dis. 2017;9:1415-9.

51. Nee J, Koerner R, Zickler D, Schroeder T, Enghard P, Nibbe L, et al. Establishment of an extracorporeal cardio-pulmonary resuscitation program in Berlin-outcomes of 254 patients with refractory circulatory arrest. Scand J Trauma Resusc Emerg Med. 2020;28:96.
52. Miraglia D, Miguel LA, Alonso W. Extracorporeal cardiopulmonary resuscitation for in- and out-of-hospital cardiac arrest: systematic review and meta-analysis of propensity score-matched cohort studies. J Am Coll Emerg Physicians Open. 2020;1:342-61.

53. Inoue A, Hifumi T, Sakamoto T, Kuroda Y. Extracorporeal cardiopulmonary resuscitation for out-of-hospital cardiac arrest in adult patients. J Am Heart Assoc. 2020;9:e015291.

54. Trummer G, Supady A, Beyersdorf F, Scherer C, Wengenmayer T, Umhau M, et al. Controlled automated reperfusion of the whole body after 120 minutes of cardiopulmonary resuscitation: first clinical report. Scand J Trauma Resusc Emerg Med. 2017;25:66.

55. Trummer G, Benk C, Beyersdorf F. Controlled automated reperfusion of the whole body after cardiac arrest. J Thorac Dis. 2019;11:S1464-70.

56. Pennel T, Beyersdorf F, Gates E, Zilla P. Neurologic recovery after ten minutes of absent cerebral blood flow at normothermia. Perfusion. 2021;36:432-4.

Key Words: ECMO, ECLS, controlled automated reperfusion of the whole body, CARL, ischemia reperfusion injury 